\title{
LEGAL RESPONSIBILITIES OF PT. LION AIR ON PASSENGER SAFETY ACCORDING TO THE LAW NUMBER 1 OF 2009 CONCERNING AVIATION
}

\author{
Eddy Pelupessy \\ Associate Professor in Faculty of Law, University of Cenderawasih, Jayapura - Papua
}

\begin{abstract}
Legal Responsibility of PT. Lion Air on Passenger Safety According to the Law Number 1 of 2009 concerning Aviation" is carried out with the aim of knowing exactly and clearly the responsibility of the airline company for passengers and the existence of laws and regulations that govern them. The type of the research was normative and sociological juridical research methods. The normative juridical research was a legal research to examine legislation and the opinions of experts in the field of air transportation law. In the context of sociological juridical research, it led an empirical method to exercise the responsibility of PT. Lion Air for passenger safety. The results of the study revealed that the responsibility of PT. Lion Air for passengers safety according to the Law Number 1 of 2009 is based on the principle of absolute responsibility, which means that PT. Lion Air is always responsible for losses incurred during the flight and does not depend on whether or not there is an element of error on the part of the carrier. Therefore, it is necessary to develop the potential and use of high technology by flight operators, as well as reliable management as an effort to protect passenger safety.
\end{abstract}

Keywords: Legal Responsibility, PT. Lion Air, Passenger Safety, Aviation Law.

DOI: $10.7176 / J L P G / 82-19$

\section{Introduction}

Commercial flight activities are part of general aviation activities and the nature of the flight itself. Therefore, ratified aviation countries conducted their activities referred to the international conventions. In the context of national law related to aviation, it is necessary to reflect on the efforts of legal formulation which must be able to enable its application to daily life in accordance with the applicable legal system.

The proliferation of airlines today can have positive implications for the people who use aviation services. This matter bring consumers to the many choices of flight operators with a variety of services. Besides that, there are many airlines have created a competitive climate between one airline and other which at the end provide to cheap tickets that are hunted enthusiastically. However, this competition on the other hand also raises concerns that the cost of cheap tickets will have an impact on the quality of services, especially services for aircraft maintenance. ${ }^{1}$

This concern arises from frequent aircraft accidents lately. It was assumed that the cheap tickets have lowered the standard of comfort and safety of passengers. Indeed then those accidents created expensive costs to pay because it related to the passengers life. Although there is no comprehensive research on the relationship between the above questions, it can be ascertained that efficiency carried out uncontrollably and unresponsible still cannot be justified for whatever reason.

From several incidents after the mushrooming of the airline, it has not seen a comprehensive effort to deal with those incidents. It cannot be denied that either the relevant institutions or the flight operators on every accident always follow up with the safest mechanism such as performing compensation or administration sanctions. There has been no holistic effort and long-term activities involving many parties to criticize whether the actions taken by the airline, the Director General of Civil Aviation, or insurance are in accordance with the provisions of the flight standards that apply universally.

As it is known that there were some accidents of commercial airplanes took place around the world including in Indonesia. In terms of the accident of commercial airplanes, it was experienced by Trigana Air, Susi Air, Mimika Air, Avia Air and Lion Air JT. 610. In the world of aviation, the accidents get important and serious attention. Therefore, what was said by the Indonesian Secretary General of the National Air Carries Association (INACA) that an aircraft did not like buses or other land vehicles. If it damaged in the middle of the road immediately, it could be repaired and then could continue the journey. The damage of the aircraft after the accident requires special procedures to inspect (examine) the accidents and it will be conducted by the authorized agency.

\footnotetext{
${ }^{1}$ Wagiman, 2006, “Reflection \& Implementation of Law”, Business Law Journal, Volume 25, YPHB, Jakarta, p. 13.
} 
The main purpose of the examination is to determine and record the facts and circumstances related to an accident. The causes of accidents as commonly known include accidents caused by human actions, by machine (in this case the plane), by environmental factors, or by management. The accidents can be also caused by several factors in combination at once. Factors of accidents caused by humans has a central role among other factors. It is because the accidents generally are caused by human errors. This perspective will be used to analyse cases of the affliction of Lion Air aircraft.

If it is looked at national and international legal instruments related to aviation, especially regarding aviation safety, they are generally relatively adequate. However, on the other hand, flight dissatisfaction with the events have be fallen domestic airlines in Indonesia is questionable. Starting from the description of the background of the problems as mentioned, the focus of this research is to what extent PT. Lion Air has responsibility to its passengers according to the Law Number 1 of 2009 concerning Aviation? and is the legislation in the field of aviation today quite comprehensive?

\section{Theoretical basis}

\section{A. Concept of Legal Responsibility}

The concept of legal responsibility from the origin of the word "concept" is sometimes used with the term "theory or principle and doctrine" without having very different meanings, including on the basis of fault liability, presumption of liability, and liability without fault. All of which including the elements and legal teachings (doctrine) are the concept of responsibility of the airlines as regulated in the Law No. 1 of 2009. It refers to international conventions, national laws, books written by experts in the field of national air law and legal practices in the field of aviation. ${ }^{1}$

To know the responsibility of the airlines as regulated in the Law Number 1 Year 2009, it is necessary to study the international conventions and national laws. The conventions are the Warsaw Convention of 1929, The Hague Protocol 1955, the Guardakraja Convention 1961, Guatemala City Protocol 1971, Additional Protocol Montreal No. 1 of 1975, Additional Protocol No. Montreal 2 of 1975, Additional Protocol to Montreal No. 3 of 1975 , Additional Protocol to Montreal No. 4 of 1975, Rome Convention 1952, and Montreal Protocol 1978. In the context of books, they are Michael Mida, ${ }^{2}$ and Rene H. Mankiewics. ${ }^{3}$ Related to some Acts, it can be seen in the 1939 Ordinance concerning Air Transport.

As mentioned above, the Law No. 1 of 2009 refers to the convention of Warsaw 1929 along with its protocols and supplements and the Rome Convention 1952 and its protocol. Therefore to know the soul of the Law No. 1 of 2009 , it needs to understand the concept of legal responsibility applied at the Warsaw convention in 1929 along with its protocols and supplements and the Rome 1952 convention and its protocol. Without knowing the applying of legal liability concept in these conventions, it will not understand well.

In air transportation, there are 3 (three) basic concepts of legal responsibility, namely the concepts of legal responsibility on the basis of mistakes, the concept of legal responsibility on the basis of presumption of guilt and the concept of legal responsibility without guilt or absolute responsibility. ${ }^{4}$ The legal responsibility on the basis of faults is contained in Article 1365 of the Civil Code. The article is known as an act against the law generally applies to anyone. ${ }^{5}$ According to the article, any act against the law that causes harm to another person requires that the person who caused his or her actions cause the loss to compensate. Based on this article, everyone must be legally responsible for their own actions, which means that if their actions cause harm to others, then the person must be responsible for paying compensation suffered. ${ }^{6}$

According to Article 1367 of the Civil Code, legal responsibility to people who suffer losses is not only limited to their own actions, but also the actions of employees, agents, and its representatives if they cause harm to others, as long as the person acts in accordance with the duties and obligations imposed on the person that is. ${ }^{7}$ This kind of responsibility is also known in the Common Law System in the Swanson Pouver VS Canada case. ${ }^{8}$ In principle,

\footnotetext{
${ }^{1}$ Fachri Mahmud, Development of Indonesian Air Transport Policy, PT. Citra Aditya Bakti, Bandung, 2004, p. 29.

${ }^{2}$ See Milda. M, Annals of Air and Space Law, Vol. XVIII, 1993, Part II, The Carswell Company Limited, Toronto, 1993.

${ }^{3}$ See Morris LC Liability in Carriage International by Air, Cases and Material, 4 Edition, Melbourne, 1977.

${ }^{4}$ See Dhaniswara K. Hardjono, Air Transport Law, PPHBI, Jakarta, 2009, p. 37.

${ }^{5}$ Munir Fuady, Act Against the Law, Contemporary Approach, PT. Citra Aditya Bakti, Bandung, 2002, p. 4.

${ }^{6}$ Agus Budi Susilo, Acts against the Law, Ar Ruzz Media, Yogyakarta, 2006, p. 29.

${ }^{7}$ Achmad Soemadipraja, Definition and Its Nature Against the Law for the Occurrence of Crime, Armico Bandung, 2002 , p. 41.

${ }^{8}$ Martono, Responsibility of Aircraft Operators to Third Parties on the Earth's Surface, Research and
} 
legal responsibility on the basis of faults applies to all airlines companies. It must meet the elements of faults, namely a loss, the victim suffered loss, and the equal position of the Defendant with the Plaintiff. If there is a fault, the amount of compensation is unlimited.

According to the concept of responsibility based on faults, if the passenger wants to get compensation for the loss suffered, the passenger is obliged to prove the mistake in question. This is clearly stated in the Law Article 28 Paragraph (2) letter a. The Law Number 13 of 1992 concerning Railways. According to the article, the passenger must prove the fault of the railway company that it is responsible for paying unlimited compensation suffered by the passenger and vice versa if there is no error or no loss the railway company will not pay compensation suffered by the passenger. Parties, both passengers and / or senders of goods and companies, prove to one another.

Responsibility based on faults must fulfill the elements of faults, namely a loss, the victim has suffered losses, and the equal position of the Defendant with the Plaintiff. The losses are related to the faults. If there is the faults, but it does not result in a loss, then the company will not be responsible. So, there are losses but the loss has nothing to do with mistakes, then the company will not be responsible. ${ }^{1}$

\section{1) Unlimited Responsibility}

If the passenger and / or shipper is able to prove the fault of the airline whether there are losses or losses resulting from the error, then the airlines must pay compensation suffered by the passenger and / or the shipper of the goods. The responsibility of the airlines are unlimited in the sense that any losses suffered by passengers and / or shippers of goods must be paid in full by the airlines, except on the basis of agreement between the two parties. ${ }^{2}$ The concept of legal responsibility based on faults is fair, if the position of both parties, passengers and / or shipper and the airline company, has the same ability to prove that they can mutually prove their fault.

In its development, the legal responsibility based on faults cannot be established in air transportation considering the position of the airline and passengers and / or shipper of goods is not balanced. It is because the airline controls high technology, meanwhile passengers and / or shipper do not master high technology. Therefore, the concept of legal responsibility based on presumption of innocence is created. ${ }^{3}$

\section{2) The Legal Responsibility for Presumption of Innocence}

In its development, the legal responsibility based on faults cannot be applied in air transportation because the position between the passenger and / or the shipper of the goods and the airline is not balanced. The position of the parties is not balanced because the airline controls high technology, while passengers and / or shipper do not master the high-tech flight. So that if the passenger and / or the shipper of the goods has to prove the fault the airline will not succeed. Since 1929, the concept was introduced the legal responsibility for presumption of innocence.

The concept of legal responsibility for presumption of innocence began to be applied in the Warsaw Convention of 1929. According to the concept of legal responsibility for presumption of innocence, the airline is considered guilty, so the airline company by law must pay compensation suffered by the passenger and / or the shipper without being proven first, except for airlines which are known as reverse proof loads. ${ }^{4}$

Passengers and / or shippers do not need to prove the fault of the airline. It simply notifies a loss that occurs during an emergency or accident landing so that passengers and / or shippers do not have to prove the fault of the airline. ${ }^{5}$ The airline is considered guilty, then in return, the airline has the right to enjoy the maximum compensation limit that has been applied in the convention or statutory regulation. It means that regardless of the loss suffered by the

Development Agency of the Department of Transportation and Telecommunications, Jakarta, 2000, p. 17.

\footnotetext{
${ }^{1}$ Armando, Legal Liability for Air Transport, Mandar Maju, Bandung, 1994, p. 28.

${ }^{2}$ See Milda Michael, Warsaw System and Limits of Liability Yet Another Crossroad, Milda Ed. Annalds of Air and Space Law, Vol. XVIII-1993 Part I, The Carswell Company Limited, Toronto, 1993.

${ }^{3}$ Abdulkadir Muhammad, Commercial Transportation Law, PT. Citra Aditya Bakti, Bandung, 2008, p. 49.

${ }^{4}$ HMN Purwasutjipto, Definition of Principal of Commercial Law, Transportation Law, Volume 3, Djambatan, Jakarta, 1994, p. 67.

${ }_{5}^{5}$ Brad Kizza, Liability Air Carrier For Injuries To Passengers Resulting From Domestic Hacking and Related To Incident, Vol. 46 (1) JALC 151 (1980).
} 
passenger and / or shipper, the airline will not be responsible pay the amount stipulated in the convention or legislation. ${ }^{1}$

In the concept of presumption of innocence, the passenger and / or shipper of the goods do not need to prove the fault of the airline, because the airline has been considered guilty. If the passenger and / or the shipper of the goods must prove the fault of the airline, it is definitely not possible to succeed, because the passenger and / or shipper do not master the high-tech flight. In the concept of the presumption of innocence, it must prove that airlines are often called the burden of proof reversing or commonly referred to as negative proof. Airlines must prove innocent. If the airline company including employees, agents, or representatives can prove innocent, then, the free airline is not responsible in the sense that it will not pay damages suffered by passengers and / or shippers at all.

As a consequence of the concept of the presumption of innocence, the airline company, by law, is responsible without evidenced first by law in respect of damage suffered by the passengers and / or shippers. However, the responsibility of the airline limited amount of compensation that stipulated in international conventions or applicable national laws and regulations for every passenger who dies or has permanent or injured defects or items lost, destroyed or damaged or cannot be used in part or in full. Whatever losses suffered by passengers will not receive compensation in their entirety. ${ }^{2}$

As stated earlier, the presumption of innocence in the airline company is considered guilty, without prior verification, however, the airline also has the right to protect itself. According to Ridwan Khairandy, ${ }^{3}$ if the airline company, including employees, agents, or representatives can prove innocent, the airlines are free to take responsibility and do not pay losses suffered by passengers and / or shippers, for example Munir's murder case on a Garuda Indonesia flight on flight from Jakarta to Schippol in the Netherlands. Garuda Indonesia easily proved that the death was not the fault of Garuda Indonesia including its employees or representatives.

The airlines not only can protect themselves, but they can also prove mistakes. If the airline company including employees, agents, or representatives can prove that the passenger and / or shipper of goods is guilty. Then, the responsibility is not entirely borne by the airline, but also charged to the passenger, for example the passenger is ordered to install a seat belt but the passenger does not comply. So if it causes a loss, it is not the sole responsibility of the airline. Concretely, an airplane crew has told passengers to use a seat belt because airplanes flying in shaky areas, but passengers ignore the warning. Therefore, if a loss arises due to an airplane shock, then the passenger is also responsible.

The responsibility of the airline is limited to a number of damages stipulated in international concessions or national legislation that apply to losses suffered by passengers and / or the shipper of goods. However, passengers and / or shippers can prove that the airlines include employees, agents or representative makes a deliberate mistake. If the passenger and / or the shipper of the goods can prove that the airline company includes employees, agents, or representatives who have made a deliberate mistake, then the responsibility limit stipulated in the convention or legislation does not apply so that responsible airlines are unlimited in any sense losses suffered by passengers and / or shippers of goods must be completely replaced. Deliberate actions, for example airplanes do not provide sufficient oxygen, even though the equipment is no item. It means that the equipment must exist, if the equipment does not exist, then the airplane may not take off. The airline can be categorized as willful misconduct.

\section{3) Legal Responsibility based on Faults}

The concept of legal responsibility based on faults or absolute (strict) responsibility is used in Article 44 of the Law Number 15 of 1992, Rome 1952 convention, Guatemala City Protocol 1971, the liability convention of 1972 , and Aircraft Product Liability, 1960 Paris Convention, Vienna convention 1963, Brussels Convention 1969, and Lugano Convention 1993. According to the concept of legal responsibility based on faults, the airlines are solely responsible for the losses suffered by third parties arising from emergency landings or the fall of goods and / or people from aircraft without requiring prior verification. ${ }^{4}$

\footnotetext{
1 Saifullah Wiradipradja, "Responsibility of Aviation Companies Against Passengers According to Indonesian Air Law”, Journal of Business Law, Vol. 25-No. 1, Jakarta, 2006, p. 7.

${ }^{2}$ Tuti Rastuti, "Responsibility of Aviation Companies Against Consumers in the Perspective of Civil Law, " Journal of Business Law, Volume 25 - No. 1, Jakarta, 2006, p. 29.

${ }^{3}$ Ridwan Khairandy, "Responsibility of Aviation Companies Against Consumers of Air Transport According to Law No. 1 of 2009", Journal of Business Law, Volume 25 - No. 1, Jakarta, 2006, p. 21.

${ }^{4}$ Wagiman, Reflection and Implementation of Air Law, Mandar Maju, Bandung, 2006, p. 13.
} 
The concept of legal responsibility based on faults applies to responsibility for aircraft operators to third parties. In the concept of absolute responsibility the operator cannot free himself from the obligation to pay losses. Words of loss can be found in Articles 18, 19, and 20 of the Warsaw convention of 1929, the Rome convention of 1952, and the liability convention of 1972. "Operator" means a person or legal entity that operates an aircraft either commercially or not commercially. It is important to cover "damages", the Supreme Court in a dispute decision between Mrs. Oswalds VS Garuda Indonesia Airways in an accident on Gunung Barangrang Bandung in 1961. It is refused demands for compensation for mental losses due to her husband's death. In the case of the fall of the JAL machine in December 2000 in Grebareng, the judge of the Central Jakarta District Court granted a non-moral loss request.

\section{B. Responsibilities in the Perspective of Civil Law}

The existence of a legal responsibility begins with an agreement consisting of rights and obligations. Based on Article 1233 of the Civil Code, the rights and obligations (agreements) are derived from agreements and laws. The agreements originating from the law is divided into legal actions and illegal acts. The emergence of agreements originating from the agreement imposes on the parties that make an agreement to carry out their rights and obligations (achievements). If one of the parties does not carry out the achievement, it can be categorized as defaulting.

Default is a situation where a debtor does not fulfill or carry out an achievement as stipulated in an agreement. ${ }^{1}$ Default (negligent) can arise due to (1) the intentions or negligence of the debtor himself and (2) the existence of a force majeure. A debtor can be said to have defaulted if: ${ }^{2}$

1. The debtor does not fulfill the achievement at all.

2. The debtor fulfill their achievements, but not as they should.

3. The debtor fulfill their achievements, but not on time.

4. D The debtor fulfill performance, but that is not required in the agreement.

In general, defaults occur if the debtor is declared negligent to fulfill the performance. In other words, defaults are if the debtor cannot prove that he has made the default beyond his guilt because of the force. If the deadline is not specified in the implementation of the achievement, the creditor is required to warn / reprimand the debtor in fulfilling his obligations. This warning is called sub-poena. The sub-poena must be submitted in writing explaining what is being demanded, on the basis of what demands are made, and at the time when it is expected that the fulfillment of the performance will be carried out. This is useful for creditors if they want to sue creditors before the court. The basis of this lawsuit is that the summons became evidence that the debtor had actually defaulted. Meanwhile, if the agreement has been determined a grace period for implementing its achievements, then according to Article 1238 of the Civil Code, the debtor is deemed negligent with the passing of the specified time. Thus, in such an agreement no subpoena of defaults made by the debtor can cause a loss to the creditor. ${ }^{3}$

According to Tuti Rastuti, in the perspective of civil law, airlines are positioned as debtors, while air transport consumers are located as creditors. ${ }^{4}$ The sub-poena will create legal consequences for default airlines are as follows:

1. Airline companies are required to pay compensation suffered by air transport consumers.

2. Cancellation of the agreement is accompanied by payment of compensation, (Article 1267 of the Civil Code).

3. Transition of risk to airlines since the time of default.

4. Payment of case fees if estimated before the judge (Article 181 paragraph (1) of the Civil Code).

Based on the Article 1267 of the Civil Code, in the case of an airline performing a default, the airline company may choose its rights in the form of:

1. Fulfillment of the agreement;

2. Fulfillment the agreement with compensation;

3. Just providing compensation;

4. Cancellation of agreement; and

5. Cancellation of agreement accompanied by compensation.

\footnotetext{
${ }^{1}$ PNH Simanjuntak, Principles of Indonesian Civil Law, Djambatan, Jakarta, 1992, p. 339.

${ }^{2}$ Abdulkadir Muhammad, Law of Engagement, Bina Cipta, Bandung, 1990, p. 27.

${ }^{3}$ R. Setiawan, Principles of Engagement Law, Bina Cipta Bandung, 1987, p. 27.

${ }^{4}$ Tuti Rastuti, Op Cit, p. 30.
} 
The obligation to pay compensation for an airline company can be implemented if the air transportation consumer has fulfilled 4 (four) conditions, namely: ${ }^{1}$

1. The airline company has indeed been negligent in carrying out defaults.

2. The airline has not been forced.

3. There is no dispute from the airlines to knock out the claim for compensation.

4. Air freight consumers have carried out summons / warnings.

Reimbursement of costs, losses and interest due to not fulfilling the air transport agreement, is only starting to be required if the airline company is declared negligent in fulfilling the agreement, or something that must be given or made can only be given or made within the time limit (Article 1243 of the Civil Code). Thus, basically compensation arises because the airline company defaults. According to the Article 1246 of the Civil Code, compensation consists of 3 (three) elements, namely:

(a) Costs.

They are all expenses for costs that have obviously been incurred.

(b) Losses.

They a loss due to damage to goods owned by air transport consumers by the fault of the airline.

(c) Interests.

They are profits that should be obtained or expected by air transport consumers if the airline is not negligent.

Basically, not all losses can be requested for replacement. The law stipulates that the losses to be paid by the airlines to air transport consumers as a result of default are as follows: ${ }^{2}$

1) Losses that can be expected when an agreement is made. Paying for real damages must or should have been expected when the agreement was made, except if the matter of non-fulfillment of the agreement was due to the deception made by him.

2) Losses are a direct result of default. According to the provisions of Article 1248 of the Civil Code, if the agreement is not fulfilled due to the deception of the airline, the payment of compensation is only about the loss suffered by the air transport consumer and the profit lost to him consists only of what is directly due to the nonfulfillment of the agreement.

The airline company is accused of being negligent and asked to give him punishment for his negligence, it could defend himself by asking several reasons to free himself from these punishments. The defence is: (1) stating the existence of a forced majeure; (2) stating that air transport consumers are negligent; and(3) stating that air transport consumers give up their rights. Overmatch / force majeure is the reason for the debtors (the airlines) to be released from the obligation to pay damages. Forcing conditions cause an achievement by the debtor (airline) to be unable to fulfill because an event occurred that is not due to his fault, the event could not be known or could not be expected to occur at the time of making the agreement. Therefore, according to Subekti, ${ }^{3}$ in the presence of force majeure circumstances, the debtor cannot be blamed and not having to bear the risk because the debtor cannot predict the event at the time the agreement is made. This situation occurs before the debtor is negligent to fulfill his or her performance at the time the situation arises. Thus, it can be concluded that in circumstances forcing the debtor cannot be blamed for not implementing the agreement, because the situation arises out of the willingness and ability or suspicion of the debtor (airline). Therefore, the debtor cannot be asked for compensation.

The elements of force majeure can be sorted as follows: ${ }^{4}$ (1) failure to fulfill performance is caused by events that destroy objects that are objects of engagement; (2) these events prevent the debtor from performing; (3) the event is unknown or suspected to occur when making an agreement both by the debtor and the creditor. So it is not the fault of the parties. The provision of the article 1244 and 1245 of the Civil Code are the basis of the defence of the debtor to be released from payment of compensation, if the debtor does not fulfill the agreement because of a coercive condition.

If the force majeure situation is created, there will be a risk. The risk can be interpreted as an obligation to bear a loss if the loss occurs beyond the fault of one of the parties that befall the object intended in the agreement. The risk regulation in the Civil Code is regulated in Article 1237 of the Civil Code which regulates risk in a unilateral

\footnotetext{
${ }^{1}$ Amran Ritonga, "Responsibility of Aviation Companies for Losses in Consumer Air Transport”, Journal of Business Law, Volume 26 No. 2 Jakarta, 2007, p. 54.

${ }^{2}$ Ibid, pp. 55-56.

${ }^{3}$ Subekti, Principles of Civil Law, Intermasa, Jakarta, 1988, p. 144.

${ }^{4}$ R. Setiawan, Op Cit, pp. 27-28.
} 
agreement, which states that in the event of an agreement to provide a certain material, the material since the engagement is born, it will be responsibility of the creditor. If the creditor fails to carry out the engagement, then since the negligence, the material is his responsibility.

A review of the responsibilities of aviation transportation company can also be based on illegal acts. The term of the illegal acts can be broadly interpreted as : ${ }^{1}$

1) Acts are against the law.

2) Acts are contrary to the principles of law.

3) Acts violate the law.

4) Unlawful actions

5) Civil fraud.

The aforementioned definition is basically the essence of the provisions of Article 1365 of the Civil Code which states that: "Every act against the law, which causes harm to others, requires that the person who by mistake causes the loss to compensate". Furthermore, in the provisions of Article 1366 of the Civil Code, it is stated that "everyone is responsible not only for losses caused by his actions, but also those caused due to negligence or inadvertence". In addition, it is stated in the provisions of Article 1367 of the Civil Code, "a person is not only responsible for the losses charged by the actions of those who are dependent or by goods under his control".

According to Article 1365 of the Civil Code, acts against the law can be prosecuted if compensation has fulfilled the following elements : ${ }^{2}$

1) This act must be against the law. An act is against the law if it is contrary to:

a) Other people's rights;

b) Own legal obligations;

c) Good decency;

d) The necessity that must be moved in the social relationship regarding the rights of others or objects.

2) These actions must cause harm. Losses caused by illegal acts can be material losses (can be valued with money). Thus, losses arising from unlawful actions are not only limited to losses aimed at property, but also to losses directed at the body of the soul and honour of man.

3) This action must have an element of error. An error can be intentional and negligent. Intentional means that someone commits an act and this action is intended to cause an effect, while negligence means not doing an action that should have been done. In other words, it can be concluded that:

(a) Intentionality in carrying out an act is when the offender is fully aware of the consequences of the action.

(b) Negligence in carrying out an act is when someone does not commit an act. By acting like that in essence he has gone against the law, because he should have to do and do something.

4) From these actions there must be a causal relationship. A causal relationship is a causal relationship between an unlawful act and a loss. This causal relationship in Article 1365 of the Civil Code can be seen in the sentence " ... which is done because of the mistake that caused a loss ...". Thus, these losses must arise as a result of one's actions. If there is no action (cause), then there is no loss (effect). So it can be concluded that the result of an act against the law is a loss. Losses as a result of violating the law cause the obligation of someone who makes a mistake and causes harm to another party to provide compensation, and on the other hand is given the right to claim compensation for the person who is harmed.

\section{Responsibilities of Air Carriers to Passengers}

The main problem of Air Transport Law, both nationally and internationally, is the problem of the responsibility of air carriers if there is a loss suffered by users of air transportation services (passengers, baggage owners, shippers, and cargo passengers). Besides that, it is also with losses that may be suffered by third parties on land (life and property). Regarding the responsibility of air carriers in Indonesia (domestic), the regulation of it can be seen in the Law No. 1/2009, the Governmental Regulation No. 40/1995, and Ordonantie of Air Carriers (OPU) No. 100/1939. Although OPU No. 100/1939 has been replaced by the Law No. 1/2009 and the Governmental Regulation No. 40/1995, some OPU provisions still apply because they have not been regulated in the new laws and regulations, such as the issue of air transport documents or ways to file claims by the victims to the transporters, and so on.

\footnotetext{
${ }^{1}$ Tuti Rastuti, Op Cit, p. 31.

${ }^{2}$ P.N.H. Simanjuntak, Op Cit, p. 354.
} 
The principle of responsibility adopted in the Law No. 1/2009 and the Governmental Regulation No. 40/1995 as stipulated in Article 43 of the Law No. 1/2009 and Article 42-45 of the Governmental Regulation No. 40/1995 is the principle of absolute/strict liability principle. It means that the carrier is always responsible for the losses incurred during the flight and does not depend on the presence or absence of the element of error on the part of the carrier, except in the case of losses caused by delays where passengers must prove the existence of an element of faults on the part of the carrier (Article 42 letter c). These articles are a substitute for Articles 24, 28, 29 and 30 of OPU No. 100/1939. The difference with OPU, the OPU No. 100/1939 states that the responsibility of the carrier is based on the principle of presumption of liability. It means that the air carrier is assumed to be always responsible unless the carrier can prove that the carrier loss / accident can prove that the loss / accident was not due to his fault.

In practice so far, whether on a domestic or international flight, if there is a loss or an airplane accident, compensation payments to the victims are always given without questioning whether or not there is an element of error from the carrier. So, the principle of absolute responsibility has been applied even though formally the Warsaw Convention still adheres to the principle of absolute responsibility. However, this Montreal Convention does not yet apply because a number of ratifications are needed that have not been reached.

The basic question on the discussion related to the legal responsibility is why is the principle of absolute responsibility enforced, not the principle on based on faults as adopted in Article 1365 of the Civil Code. If the principle of responsibility on based on faults applied in air transportation is certainly very difficult for the victims (who are generally lay people in the world of aviation) because the victim can prove the existence of an element of error on the part of the airline (defendant). Even though it is almost certainly impossible for the victims to prove what actually happened in the world of aviation that caused an airplane accident. Not to mention the process in the court will take quite a long time with a considerable cost too, even though it is not necessarily he won the case. Thus, the application of the principle of absolute responsibility in air transportation will make it easier for victims to obtain compensation in a fast process as well. Except, in certain cases (if the victim or his family suspects there is an indication of an element of extraordinary negligence on the part of the transporter that causes the carrier to be liable indefinitely), he can file a claim before the court.

\section{Research methods}

The research location was the airline PT. Lion Air in Sentani, Jayapura and related technical agencies based in Jayapura. The type of legal research used was normative juridical and sociological research. The normative juridical research examined the laws and opinions of experts in the field of air transportation law. While, the sociological research led an empirical reality, especially regarding to the responsibilities of airlines.

The number of respondents in this study were 24 (twenty four) people, which consisted of:

1) Community users of air transportation services PT. Lion Air in the Regency and the City of Jayapura as many as 29 people.

2) The leadership and operational staff of PT. Lion Air as many as 2 people.

3) Officials of Transportation Agency of the Papua Province, Cq in the Air Transportation Sector as many as 2 people.

4) Air Transport Legal Experts as many as 1 person.

The collected data were then analysed qualitatively using interactive models including the stages of data reduction, data presentation and conclusion drawing. The data analysis applying this model, aaccording to Patton as quoted by Lexy J. Maleong was the process of arranging data sequences, organizing them into a pattern, category, and basic description. ${ }^{1}$

\section{Research Results and Discussion}

\section{A. Responsibilities of Flight Companies PT. Lion Air Against Passengers}

For the sake of keeping information regarding the causes of Lion Air PK-LQP B737 Max 8 aircraft accidents with flight number JT610 continue to be collected, the National Accident Transportation Committee (NTSC) found data that before crashing, the aircraft with the manifested 189 people lost contact when the new height reached 2,500 feet. Allegedly, the pilot did not get altitude instructions. Other data shown, after the Boeing manufacturer's aircraft hit the sea surface hard, the two engines were alive with high RPM (Per-Minute Rotation). This finding also disputed the theory that JT610 exploded in the air. This was reinforced by the findings of the plane that was found in small form.as it is known, if it exploded in the air, debris tended to be bigger. The speed was quite high

${ }^{1}$ Lexy J. Maleong, Qualitative Research Method, PT. Remadja Rosdakarya, Bandung, 1999, p. 103. 
so that the debris indicated that the energy releasing at this time was extraordinary according to the Head of NTSC, Sarjanto Tjahjono. Another finding also was published by NTSC. It was information from the Flight Data Recorder (FDR) which shown that before the contact lost and fell, JT610 suffered damage to the air speed indicator or air speed indicator. In fact, unreadable damage on the last four JT610 flights included the route of the outbreak of the Jakarta-Pangkal Pinang event. Among the findings concluded the damage as revealed by the NTSC, it was the difference in air speed indicator information on the pilot screen and the co-pilot. Basically, the two monitors should contain the similar information related to the speed indicator.

For a number of findings, the NTSC carried out a conformation with the Boeing manufacturer which produced the 737 Max 8 type. In addition, the NTSC was also asking for information from technicians and pilots who flew JT610 on crucial routes before. The NTSC also checked aircraft maintenance logs which should record the complaints of pilots on previous routes. Although it has been revealed that the problem at airspeed, the NTSC has not yet concluded the main cause of the accident. According to Nurcohyo Utomo, the Head of the Investigation Sub-Committee, a number of findings confirmed that before taking the Jakarta-Pangkal Pinang route, while undergoing the Denpasar-Jakarta JT610 route, there had been technical problems. Based on the information of the Black Boy, what was meant by technical means was the problem of airspeed or the speed of the plane. Not only that, on two flights before taking the Denpasar-Jakarta route, the same damage was found. The NTSC and its team were still examining the cause of the damage and how the solution was repaired and how the pilot flew the plane that had been damaged on the previous flight. Does the problem come from indicators, gauges or problems with the computer.

The LoC Cost Carrier (LCC) business scheme has always been a matter of criticism when complaints about schedule damage and especially accidents on airplanes arise from low-cost aviation science. The principle of suppressing the cost component that affects ticket prices (for example by not providing food and drinks, entertainment facilities, without travel ticket agents and others) is often a polemic when it is hit with safety and security variables. So far, the airline has reduced ticket prices by reducing the service component in the pre-flight, in flight, and post flight. This is regulated by the Minister of Transportation Regulation No. 49 of 2012 concerning Domestic Aviation Service Standards.

Efficiency during pre-flight, for example, is done by selling tickets directly through the website and online checkin. Efficiency in flight, in addition, not only provides food and drinks for passengers, but also changing the distance between passenger seats closer. It means that the airlines can add more seats. The efficiency of post flight can be done by shortening the ground time at the airport.

In the case of JT610, the question is whether the efficiency practice carried out by the airline Lion Air in such a way to ignore the safety factor? The investigation carried out by the NTSC and the Ministry of Transportation Authority has not yet reached that conclusion. It is clear that JT610 was very busy flying before finally crashed. The JT610 had travelled 23 hours 60 minutes on 11 flight routes before the fateful day. As it is known, before taking the route, the shortest rest time was 40 minutes after taking the Denpasar-Lombok route on Saturday, October 27. The longest route was 15 hours 10 minutes according to the Denpasar-Manado route, on October 28.

Previously, JT610 travelled the International route on Friday, October 16, from Shanghai Padang Airport to Denpasar with a distance of $4,471 \mathrm{Km}$. Four and a half hours later drove to Manado. Then return to China with the Manado-Tiamin route, which was 4,237 Km in 5 hours 18 minutes. On the same day, the plane returned 1 hour to 41 minutes to Manado. The intensity was thought to underlie the contents of the bock log that was widely circulating on social media which revealed the attack and speed of the problematic plane.

According to Budi Mulyawan Suyitno, Aviation industry observer, the safety management system was the key to seeing the operational negligence in the JT610 aircraft accident. The safety management system has several elements of latent failure that usually came from institutions or organizations whether the airlines have implemented a safety management system properly, and that can be checked. The safety management system records all data and flight history. Recording must be trusted and can be traced by the regulator, so that when there is an indication of deviation or declining quality there is a warning to maintain the quality of security and safety.

To see the implementation of the safety management system, it must be seen also the airline's track record for the past 15 to 16 years. In fact, since 2002 Lion Air's plane have suffered 21 total accidents, for example the accident in Solo in 2014 and the last in Karawang. Some other calculating Lion Air's track record of being sanctioned by the Ministry of Transportation can be considered as part of the safety management system for example the 
employee strike case in 2016 and the decrease in passenger incidents that caused passengers to fly from JT611 from Singapore through the immigration counter.

The last incident made the Director General of Air Transportation at that time, Suprasetyo, enforced permits starting on May 11, 2016. Then, Lion was forced to improve his basic service system. However, in the airline's business practice, it must be controlled by the government so that airlines with the LEC business line still maintain the safety factor in the air. There are rules from the government, now the highest platoon is $100 \%$ and flexible up to $30 \%$. Indeed, the $30 \%$ is very cheap. In order for the lower flight tariff limits to be loaded more flexibly to keep the airline's attention to safety factors. It can be above $30 \%$ and flexible up to $70 \%$. The point is in the LEC concept, all the cost components can be saved, except the matter of safety. The increase in lower limit rates can be balanced with supervision. If it's very cheap, it's comfortable. Safety is a top priority.

The Minister of Transportation, Budi Karya Sumadi stated that the deadline for determining sanctions for Lion Air in the aftermath of the accident, now has special audits of Boing 737 Max 8 and examined Lion Air's standard operating procedure (SOP), as well as organizational audits. There is the possibility of human error factor in the incident of JT610, especially the possibility of technician error. The Lion Air need to be clarified by the NTSC whether the sanction will lead to personal or management. As stipulated by the Indonesian House of Representatives Commission V, Ferry Djemis Francis, that the commitment to safeguarding zero incidents in the aviation industry must be the main target of all airlines, including those engaged in low-cost airlines. Airlines must calculate to issue ticket prices that can cover maintenance and operational costs. They do not just have profit orientation. It must reset the lower flight tariff limits for increased safety.

According to several aviation experts, Lion Air is a category of airlines with the lowest level of safety. In 2004, when 4 years of operation Lion Air 538 crashed in the cemetery in Solo, Central Java, 25 passengers were killed. Then in 2011, the Lion Air plane landed with the aircraft's hull hit the runway at Sipardin Airport in Pontianak, 174 passengers and flight crew were successfully evacuated. On April 13, 2013, flight 904 from Bandung to Denpasar with 108 passengers inside crashed into the waters of Bali, after surpassing the runway at landing. In 2014 two passengers were injured and 3 others were slightly injured when Boing 737-900 landed hard on the Juanda Airport runway in Surabaya and bounced 5 times before hitting the ground.

To solve the above problems, it is necessary to review national and international legal instruments related to aviation, both public or private air law. Some transportation law experts argue that the differences between the two things are difficult because air law is not determined by the nature of the legal relationship that controls the rules of air law, but is determined by its object, namely air. The public air law is differentiated into international public air law which includes conventions and customs regarding air use for aviation interests which apply to flights between countries and other countries, and national public air law which includes regulations based on a country's national law to flight interests. Similar to the private air law, it is divided into international private air law which contains rules regarding legal relations between people and people or with legal entities that constitute or are born from flights. While the national private air law includes rules regarding the legal relationship of people with people or with legal entities born / arising from the operation of aviation.

Looking at international aviation legal instruments, the first international convention was in 1919 namely the convention of the regulation of aerid navigation better known as the Paris convention which was signed by 27 countries. This Convention regulates international air traffic relations. In 1929 the Liberian American convention was born again which applied to Latin American countries. All of the conventions as mentioned were held at the Chicago Convention in 1944. Another important convention which was impossible to abandon in discussing aviation was the Convention for certain rules relating to international carriage by air or commonly known as the Warsaw convention of 1929.

The Warsaw Convention regulates transport liability in international air flight. According to this Convention, it involves being responsible for losses suffered by passengers unless the carrier can prove that it has taken all measures to prevent the loss. If it cannot prove a loss, the airlines must compensate for a sum of money. The Warsaw Convention has given a new milestone to the emergence of the principle of the presumption of liability and the principle of limitation of liability. The Warsaw Convention was later renewed through a diplomatic conference in The Hague which later gave birth to the 1955 The Hague Protocol. In 1961, the Guaddaraja Protocol was reborn whose contents changed the Warsaw Convention related to other carriers who were parties who did not participate in the signing of the contract. In 1977, the Guatemalan Protocol was reborn which changed and added to the Warsaw Convention which had been amended by The Hague Protocol 1955. The Guatemala Protocol stipulates absolute liability of the carrier in connection with the 
death or injury of passengers that occurred during international air transportation. In addition, there are still other protocols / conventions that are not directly related to this subject.

Associated with national legal instruments, since Indonesia has gained independence, the legal provisions regarding flight were relatively adequate. In $1933 \mathrm{Stb}$ appeared. 118 Luchtvaart Besluit who regulated the points of flight. In 1934 followed by Luchtvaart Ordantie Stb 1936 No. 425 concerning the Implementation Regulation of Luchtvaart Besluit, born. In 1936, Luchtverkeesverordening Stb 1936/425 which regulated air traffic. In the same year also was determined Verordening Toezicht Luchtvaart Stb 1936 No. 426 which was a flight control regulation (license, safety, airworthiness and inspection of causes of accidents. In 1939 Luchtvaarquarantie Ordonantie Stb. 1939 No. 149. In 1939 , it also appeared Ordinance Luchtvervoer Stb. 1939 No. 100 namely ordinance concerning air transportation which regulated the responsibility of the carrier and is civil. In 1958. Law No. 93 of 1958 concerning Aviation which also simultaneously revoked Stb. No. 118 Luctvaart besluit governing Flight Principles and Luchtvaart Ordantie Stb 1936 No. 425 concerning Luchtvaar's Besluit. Luchtverkees verordening Stb 1936 No. 426 governed a flight control regulation such as license, safety, airworthiness, and inspection of causes of accidents). The Law No. 93 of 1958 was then renewed through Law Number 1 of 2009.

The important operational provisions are used as the basis for reviewing the case of Adam Air's aircraft including the Government Regulation Number 45 of 1995 concerning Air Transport, the Government Regulation Number 3 of 2001 concerning Aviation Safety and Security, and the Minister of Transportation Decree Number KM 1 of 2004 concerning Notification and Accident Reporting, events or delays in Arrival of Aircraft and Aircraft Investigations of Accidents / Events on Aircraft.

Aviation safety related to the conduct of flight operations and requirements in accordance with operational and flight eligibility requirements along with supporting flight. The level of flight safety of a country can be sought by dividing the number of accidents per year divided by the number of take- offs and landings per year. Relation to operations, the aircraft have to have a valid and null of an Airworthiness Certificate (STKU). The technical requirements for obtaining STKU are regulated in the Civil Aviation Safety Regulations book following the ICAO standard. Problems are often faced in this case, the application of regulations for aircraft operators varies to meet the technical requirements needed. This is due to economic factors and human resource expertise of an operator.

Some other important aspects to realize flight safety include the medical aspects of aircraft, are pilots. Personal aspects of pilots must meet the requirements as stated in ICAO Annex I. Diseases watch out for flight crew include kidney stones, epilepsy, and the heart. In the daily lives of pilots, attention must also be given to avoiding problems that will cause or affect emotional stability during the task. In addition to the flight crew, officers on the ground are also important for achieving flight safety that is directly related to aviation safety is the officer on the air traffic controller and mechanics. For mechanics also should not be colour blind, because if so can be wrong in connecting the cables with different colours. Other supporting fields are telecommunications, as well as radio and navigation.

Airworthiness supervision covers the process of making and maintaining aircraft. In the maintenance process, it is the factory's obligation to provide instructions on aircraft maintenance in manual form. The maintenance instructions state the time limit and interval of drilling and replacement of aircraft components. According to civil aviation safety regulations, aircraft operators are obliged to maintain their aircraft based on maintenance specifications that are authorized and must be carried out by experts who have the capacity. When paying attention to the Adam Air case, the source of the news mentioned was related to damage to navigation and communication equipment.

In terms of flight accidents, two terms are known, namely aircraft accident and air accident incident. Aircraft accident is an event related to the operation of an aircraft that occurs between the start time when someone boarded an aircraft with the intention of flying until the time when the person descended from the plane, and during that time one person died or suffered severe injuries due to being on a plane or direct connection by plane. It is also possible for an aircraft to experience an accident, while the term aircraft incident is used for events or events other than aircraft accident related to aircraft operations that affect its operational safety.

Basic questions after an accident are what must be done immediately. For this matter, it can be referred to: the annex of the Decree of the Minister of Transportation Number KM. 1 of 2004 concerning Accident Notification and Reporting, Events or Delays in Arrival of Aircraft; and Civil Aviation Safety Regulations (PKPS) Section 830 in section A. In the point of 830.5 of General Section, it states that "in the reporting procedure, it is confirmed that each civil air operator must be as quickly and with the best facilities available to notify the NTSC and Director 
General of Civil Aviation (DGCA) and the local government at the time of the accident. In the point (c) sub-section (a), the point is that the aircraft operator who had an accident or incident was told to the authorities responsible for safeguarding all contents (including the plane itself) until it is taken over by the NTSC. In sub-section (b), it is stated that until the NTSC or the Directorate General of Education or the responsible representative takes over the guarding, the aircraft may not be disturbed or moved. For the last thing there are exceptions, namely: 1) to move passengers who are injured or trapped inside it, 2) to protect the collapse of further damage or, 3) to protect people who may be injured. If the exception is made in the settings in subsection (c) stated, if to remove the debris, sketches, notes and photographs must be made original positions and conditions of collapse and important signs of collision NTSC is a committee having the authority to fulfill Indonesia's obligations in Annex 13 of the Chicago Convention on the International Civil Aviation Organization(ICAO). This committee is a non-structural institution within the Ministry of Transportation related to investigations from transportation accident research.

Legal responsibility of the airline PT. Batik Air begins with the transportation agreement. On the shipper's side, he is obliged to (1) take the passenger from the place of departure to the destination safely, (2) the carrier is obliged to replace the loss caused by the injury, except if the injury is caused by an event that cannot be prevented or avoided or because of the fault of the passenger himself, (3) fulfill the agreement as specified in the agreement clause stated in the ticket, for example the accuracy of the flight schedule, suitability of the travel route, and so on.

In addition, the carrier is charged with the obligation to prepare the feasibility of flying a plane to achieve passenger security and safety. On the passenger side, it is required to pay the ticket price in accordance with the agreement. If one of the parties does not carry out the achievements as agreed upon, the party can be categorized as having defaulted. The problem is whether the airline PT. Batik Air has defaulted or is the airline company PT. Batik Air is in an overmacht. If there is a default, whether it is the source of intentional or negligent. If the incident associated with navigation damage, it should be investigated whether the navigation error occurred from the time of departure. If so, then the flight of PT. Batik Air uses aircraft that are not flying. However, if the navigation damage is in the middle of the trip, there are two possibilities, that is, it can be categorized as default or an overmacht situation occurs. If indeed the condition of the aircraft has an APU problem since the previous six months, thus the situation of the event can be expected to occur.

The question then is the state of default of the airline PT. Batik Air needs subpoena?. The answer is no. It is because if the agreement has been determined a grace period for implementing its achievements, then according to Article 1238 of the Civil Code the debtor is deemed negligent with the passing of the specified time. As such, subpoena is not required for such an agreement. To provide compensation to the passengers, the airline company PT. Batik Air can prove that he has made a default that is beyond his fault or because of a forced situation. Based on the Article 1267 of the Civil Code, the airline company PT. Batik Air as a debtor who defaults is subject to demands for rights that can be chosen by service users in the form of fulfilling the agreement along with compensation. As determined in Article 1246 of the Civil Code, compensation consists of 3 (three) elements, namely: (1) costs, namely all expenses or costs that have actually been incurred, (2) loss, (3) interest, that is profit which should be obtained or expected by creditors if the debtor is not negligent.

The law stipulates that the loss to be paid by the debtor to the creditor as a result of default is a loss that can be expected when the agreement is made. According to Article 1248 of the Civil Code, if the agreement is not fulfilled due to the deception of the debtor, the payment of compensation is only about the loss suffered by the creditor and the profit lost to him is only what constitutes the direct result and failure of the agreement. In addition to the responsibility of the airline company PT. Batik Air is based on default as described above, there is also a study of legal responsibility. This action is basically the essence of the Article 1365 of the Civil Code as stated that "Any act against the law, which causes harm to others, requires that the person who by mistake causes the loss to compensate". Furthermore, in the Article 1366 of the Civil Code, it is stated that "Everyone is responsible for not only the loss mentioned because of his actions, but also those caused due to negligence or reduced caution". In addition, it is stated in the Article 1367 of the Civil Code that: "A person is not only responsible for losses caused by his own actions, but also for losses caused by the actions of those who are dependent or caused by goods under his control".

The emergency landing event of the airline PT. Batik Air, if caused by navigation errors and errors in the APU system, can be reviewed based on legal aspects, including civil aspects in general, air transportation legal aspects, air transportation legal aspects, consumer protection legal aspects, corporate legal aspects, criminal law aspects, administrative aspects, and so on. Contrary to the rights of competitors (rivals) of other airlines and the rights of service users, applied provisions are based on the aspects of competition law as stipulated in the Law Number 5 Year 1999, specifically unfair business competition and prevent flight service users from choosing substitutes for other aviation services by providing incorrect information, so that consumers using PT. Batik Air . 
Basically, legal obligations of the airline company PT. Batik Air itself against APU damage has occurred in several instances including the emergency landing of PT. Batik Air at Sultan Hasanuddin Airport Makassar. It has implications for legal obligations that are not implemented, namely repairing the APU, carrying out flight feasibility that ensures passenger safety, and security.

The negligence carried out by the airlines is an act that should be done, namely repairing the APU which is already known to be problematic. The flight company PT. Batik Air is fully aware of the consequences of these actions. As for negligence in the feasibility of navigating such an attitude to the essence of the airline PT. Batik Air has been against the law because it should have to do and do something, from this action there must be a causal relationship. The element of error and loss is a causal relationship. Navigation errors and the APU system caused the aircraft to be unfit to fly and make an emergency landing. Of course these events cause losses to service users both material and immaterial losses.

The airline company PT. Batik Air can defend itself by asking a number of reasons to free itself from punishment. The defence is only proof that the PT. Batik Air can prove an overmacht. Overmacht which can be stated in the form of overnacht that is relative, which causes an achievement that cannot be fulfilled not because of its fault, but cannot be known or cannot be predicted to occur when making an engagement. The most basic burden of proof is to deny the existence of an "error" element, the existence of an element of "compulsion" from the airline PT. Batik Air so that it cannot be blamed and does not have to bear the risk, then the element that the Batik Air cannot predict will be an event of navigation failure and damage to the APU and loss of direction at the time of the departure agreement.

\section{B. Analysis of Implementation Aviation Law}

When viewed from the application of the principle of absolute responsibility in legislation in the field of air transportation in Indonesia today, this is very encouraging. Thus, if there is an accident or loss suffered by a passenger or third party on land / sea, the victim will get compensation automatically, without having to take a prolonged process. However, there are several issues that still need to be addressed, including:

1. There needs to be a clear separation between laws on public and private issues. The Law Number 1 of 2009 concerning Aviation is public in nature and should not regulate some civil issue in detail, for example regarding commercial air transportation. Meanwhile, the flight carried out by the state or the military and the National Police is not sufficiently regulated. The Aviation Law simply regulates general matters concerning various aspects as references or references to more specific and detailed laws and regulations. As in the international arena, there is a Chicago Convention in 1944 which regulated the public and conversion matters of Warsaw 1929 (now the Montreal convention 1999) which regulated commercial flights.

2. The amount of compensation should not be included permanently in the law or government regulation (fixed amount), but is determined based on legislation that allows it to be easier to make changes (e.g. Ministerial Regulations). This is to anticipate the inflation rate or the rupiah exchange rate at a certain time period in accordance with the country's economic development.

3. There needs to be strict law enforcement against airlines that violate applicable laws and regulations, especially those relating to aviation security and safety, including the practice of competition between companies that are not fair and unhealthy.

4. There needs clear and decisive government policy regarding permits for airlines operating in Indonesia to not turn off national flights.

5. It is necessary to immediately review the laws and regulations in the field of aviation to make it more comprehensive, systematic, clear, not overlapping, and consistent.

6. The problem of commercial air transportation is not enough to only be regulated by government regulations. It should be governed by the law and the material regulated is very broad and should be transformed from the International Convention into national legislation.

\section{Conclusions}

A. The responsibility of the airline company PT. Lion Air for passengers according to Indonesian air law is the principle of absolute responsibility. As stipulated in Article 43 of the Law Number 1 of 2009 concerning Aviation and Article 42 to 45 the Government Regulation No. 40 of 1995. It means that the carrier (airline) is always responsible for losses incurred during the flight and does not depend on whether or not there is an element of error on the part of the carrier. In practice so far, whether on a domestic or international flight, if there is a loss or an airplane accident, compensation payments to the victims are always given without questioning whether or not there is an element of error from the carrier. 
B. The principle of absolute responsibility indicates that the application of laws and regulations in the field of aviation is sufficient, but there are still some problems that still need to be addressed, including the need for explicit separation between laws that regulate public matters and private matters.

\section{Bibliography}

Abdulkadir Muhammad, Commercial Transportation Law, PT. Citra Aditya Bakti, Bandung, 2008.

----------, Law of Engagement, Bina Cipta, Bandung, 1990.

Achmad Soemadipraja, Definition and Its Nature Against the Law for the Occurrence of Crime, Armico Bandung, 2002.

Agus Budi Susilo, Acts against the Law, Ar Ruzz Media, Yogyakarta, 2006.

Amran Ritonga, "Responsibility of Aviation Companies for Losses in Consumer Air Transport", Journal of Business Law, Volume 26 No. 2 Jakarta, 2007.

Armando, Legal Liability for Air Transport, Mandar Maju, Bandung, 1994.

Brad Kizza, Liability Air Carrier For Injuries To Passengers Resulting From Domestic Hacking and Related To Incident, Vol. 46 (1) JALC 151 (1980).

Dhaniswara K. Hardjono, Air Transport Law, PPHBI, Jakarta, 2009.

Fachri Mahmud, Development of Indonesian Air Transport Policy, PT. Citra Aditya Bakti, Bandung, 2004.

Lexy J. Maleong, Qualitative Research Method, PT. Remadja Rosdakarya, Bandung, 1999.

HMN Purwasutjipto, Definition of Principal of Commercial Law, Transportation Law, Volume 3, Djambatan, Jakarta, 1994.

Milda. M, Annals of Air and Space Law, Vol. XVIII, 1993, Part II, The Carswell Company Limited, Toronto, 1993.

Milda Michael, Warsaw System and Limits of Liability Yet Another Crossroad, Milda Ed. Annalds of Air and Space Law, Vol. XVIII-1993 Part I, The Carswell Company Limited, Toronto, 1993.

Morris LC Liability in Carriage International by Air, Cases and Material, 4 Edition, Melbourne, 1977.

Munir Fuady, Act Against the Law, Contemporary Approach, PT. Citra Aditya Bakti, Bandung, 2002.

Martono, Responsibility of Aircraft Operators to Third Parties on the Earth's Surface, Research and Development Agency of the Department of Transportation and Telecommunications, Jakarta, 2000.

PNH Simanjuntak, Principles of Indonesian Civil Law, Djambatan, Jakarta, 1992.

R. Setiawan, Principles of Engagement Law, Bina Cipta Bandung, 1987.

Ridwan Khairandy, "Responsibility of Aviation Companies Against Consumers of Air Transport According to Law No. 1 of 2009”, Journal of Business Law, Volume 25 - No. 1, Jakarta, 2006.

Saifullah Wiradipradja, "Responsibility of Aviation Companies Against Passengers According to Indonesian Air Law”, Journal of Business Law, Vol. 25-No. 1, Jakarta, 2006.

Subekti, Principles of Civil Law, Intermasa, Jakarta, 1988.

Tuti Rastuti, "Responsibility of Aviation Companies Against Consumers in the Perspective of Civil Law," Journal of Business Law, Volume 25 - No. 1, Jakarta, 2006.

Wagiman, Reflection and Implementation of Air Law, Mandar Maju, Bandung, 2006.

---------, 2006, “Reflection \& Implementation of Law”, Business Law Journal, Volume 25, YPHB, Jakarta. 